\title{
A new genus of Chrysomelinae from Australia (Coleoptera: Chrysomelidae)
}

\author{
CHRIS A. M. REID ${ }^{1}$, JOSÉ A. JURADO-RIVERA ${ }^{2} \&$ MAX BEATSON $^{3}$ \\ ${ }^{1}$ Department of Entomology, Australian Museum, 6 College Street, Sydney, NSW 2010. E-mail: chris.reid@austmus.gov.au \\ ${ }^{2}$ Universitat de les Illes Balears, Departament de Biologia, Laboratori de Genètica, Carretera Valldemossa Km 7.5, C.P. 07122, \\ Palma de Mallorca, Spain. E-mail: jajurad@gmail.com \\ ${ }^{3}$ Department of Entomology, Australian Museum, 6 College Street, Sydney, NSW 2010. E-mail: max.beatson@austmus.gov.au
}

\begin{abstract}
A new genus, Canobolas Reid, Jurado-Rivera \& Beatson, is erected for four species of Chrysomelinae: C. nobilis (Lea) (comb. nov. from Geomela Lea, and type species), C. jarrah sp. nov., C. minang sp. nov. and C. tubrabucca sp. nov., all of which are described. Canobolas is endemic to Australia, where it is confined to the far western and eastern edges of the continent. All species are flightless, with narrow ranges. Feeding has not been observed and immature stages are unknown but the hostplant range may be wide, by inference from plant DNA sequenced from one specimen of $C$. nobilis. Canobolas is compared with other genera of Chrysomelinae.
\end{abstract}

Key words: leaf-beetle, morphology, taxonomy, plant DNA

The leaf-beetle subfamily Chrysomelinae, with approximately 3000 species worldwide, is particularly diverse in Australia, where there may be 750 species (25\% of the world species; Reid 2006a). Generic level diversity of Chrysomelinae in Australia is also comparably high, although imprecise due to the unstable classification of the world genera. The first modern checklist included 176 genera (Daccordi 1982), the second, by the same author, 133 (Daccordi 1994)., but the underlying evidence for the changes has not been provided (Reid 1995, 2006a). Nevertheless, if there are between 133 and 176 world genera, a significant portion is native to Australia: 42 (Reid 2006a), which is between $24 \%$ and $32 \%$ of the world fauna.

Detailed study of the Australian fauna is clearly a prerequisite for any study of the systematics of the subfamily and a taxonomic review of the Australian genera has been undertaken, defining genera along cladistic lines, but without testing these hypotheses and utilising only adult characters (Reid 2006a). Further work is required to test monophyly of the genera and to determine their relationships within the world fauna. In particular, the speciose genera dominated by small-sized species, for example Peltoschema Reitter and Geomela Lea, need to be reassessed (Reid 2006a). The morphological part of this work is being undertaken by CAMR and the molecular by JAJR. To this end a number of collecting trips were undertaken in 2005-2006, during which we rediscovered Geomela nobilis Lea, which on morphological grounds was wrongly placed in Geomela and does not easily fit into any existing named genus.

A new genus is raised for this species, and for three similar undescribed species discovered amongst material in Australian collections, and all taxa are described below. The morphological character set which was formulated to define and distinguish the genera of Australian Chrysomelinae (Reid 2006a) is used for description of the new genus.

Abbreviations: AMS = Australian Museum, Sydney; ANIC $=$ Australian National Insect Collection, Canberra; BMNH = Natural History Museum, London; MMS = Macleay Museum, Sydney; SAM = South Australian Museum, Adelaide. 


\section{Canobolas Reid, Jurado-Rivera \& Beatson, gen. nov.}

Type species. Geomela nobilis Lea, 1917, this designation.

Description (adult). Length 3.5-6.0mm; body (Figs 1-8) almost circular to elongate-ovate, length 1.1-1.7x width, moderately to strongly convex in profile, length 1.7-2.4x height. Dorsum dark reddish-brown to black, with or without slight metallic green or blue reflections, glabrous except a few recumbent setae above antennal insertions.

Head (Figs 4, 8, 9, 11-14): fronto-clypeus smooth, without antero-lateral ridges and with an arcuate groove or shallow depression between (but not reaching) bases of antennae, which are adjacent to eyes; vertex obliquely grooved posteriorly from inner margin of each eye (groove often hidden by overlapping prothorax); eyes strongly transverse (narrow in dorsal view), height c. 3x width, partially ventral, inner margin shallowly concave; eye laterally projecting, anteriorly truncate and posteriorly abruptly constricted to parallel-sided head capsule, temples absent or almost so; antennae situated on anterior margin of head; venter of head with deep and smooth elongate subantennal groove, length c. $3 \mathrm{x}$ width, bounded by ridges, for retention of antenna between eye and mouth; antennae c. 0.3-0.6x body length, antennomere 1 enlarged, ovate, 2 short (half length of 1), 3 relatively narrow and elongated (length 2.5-3.5x width), 6 reduced, shorter than either 5 or 7, 7-10 expanded from base to apex, length $0.9-1.7 \mathrm{x}$ width; labrum not densely setose, with 3-5 pairs of prominent setae; mandible with two apical teeth and thick membranous pad (pulvillus) near middle of inner margin; apical maxillary palpomere elongate, cylindrical or fusiform, preapical palpomere triangular, shorter than apical and of similar width; first maxillary palpomere without groove or ridge to receive second palpomere; mentum transverse, width c. 3x median length, but anterior angles narrowly produced.

Thorax (Figs 1-9, 15-18): pronotum transverse, broadest at base, evenly convex in cross section or with feeble lateral depressions; anterior edge concave, posterior convex and lateral edges slightly convex; anterior and sides distinctly margined, base without margination; anterior angles rounded, posterior angles approximately $90^{\circ}$; pronotum without trichobothria, angles non-setose; hypomeron impunctate, without groove; prosternum with strong oblique ridge anterior to each coxa, for retention of antennae; prosternal process about as broad as long, or slightly broader, truncate, evenly expanded to apex, with lateral ridges converging anteriorly at or just before anterior margin of prosternum; procoxal cavities open, gap at least half width of procoxa; scutellum with rounded apex; elytra evenly convex, without basal or lateral depressions, with scutellary striole and 8 complete regular striae, $9^{\text {th }}$ present at least in basal third, $10^{\text {th }}$ present as series of large punctures above epipleural margin; elytral epipleuron narrow, width $<0.2 \mathrm{x}$ elytral width, entirely visible laterally, slightly sinuate, gradually contracted from base to apex, and without setae; anterior elytral wingbinding patch on oval swelling one third from base; mesoventrite visible between prosternal process and metaventrite, medially reduced to short strongly transverse (width $>3 x$ length) median process, with shallowly concave apex, and laterally reduced to a thin arcuate ridge between each mesocoxa and prosternal process; anterior of mesoventrite process abruptly declivous to accommodate prosternal process; wings entirely absent; metaventrite evenly microreticulate, strongly transverse, width $3-4 x$ length, with deep median depression and anterolateral margins flattened and expanded as smooth areas (femoral plates); metepisternum smooth, not longitudinally grooved; metendosternite with short basal stalk and thin recurved lobes at apices of lateral arms; all femora flattened, slightly fusiform to almost parallel-sided, ventral surfaces defined by paired longitudinal ridges; all tibiae flattened, with one dorsal and two ventral keels, expanded from narrow base to beyond middle, then dorsally excavate before apex to accommodate first tarsomere; all first tarsomeres with ovate patch of spatulate setae in males, with dense non-spatulate setae diverging from midline in females; apex of third tarsomere shallowly concave; claws simple, without basal tooth.

Abdomen (Figs 3, 10, 15-24): pygidium deeply grooved from base to apex along midline, groove rectangular in cross-section, gradually narrowed from base to apex; tergite VIII with distinct spiracles; ventrites free, not fused, ventral surfaces of I and V laterally bound by elevated ridges; ventrite I with intercoxal process truncate at apex, anterior border flattened and expanded behind coxae (femoral plates); 
ventrite V smooth, not medially depressed, and truncate at apex in both sexes, but male with transverse rectangular internal flange; sternite IX of male reduced to two separate struts; male tegmen present, V-shaped; penis simple, flattened tubular, with small basal foramen, $<0.3 \mathrm{x}$ length of penis; base of penis with longitudinal split; female tergite 8 well-developed, sternite 8 with long, thin, basal apodeme (C. nobilis) or with short bifurcate apodeme $(C$. jarrah); ovipositor with pair of well-developed paraprocts, partly enclosing basal half of palpi, and pair of weakly sclerotised and poorly defined elongate proctigers dorsal to these; vaginal palpi 2-segmented, second segment large and elongate; spermatheca falciform, with long coiled spermathecal duct which is expanded at attachment to bursa copulatrix.

Distribution and biology. Canobolas is endemic to Australia (Fig. 25), where it occurs in the South-west, Southeastern New South Wales and McPherson-Macleay bioregions (Crisp et al. 1999). Western localities are low altitude $(<500 \mathrm{~m})$, dominated by closed eucalypt forest, whereas eastern localities are high altitude (at least $>800 \mathrm{~m}$, probably $>1100 \mathrm{~m}$ ), in subalpine woodland (Fig. 26). Each species is known from only one or two localities.
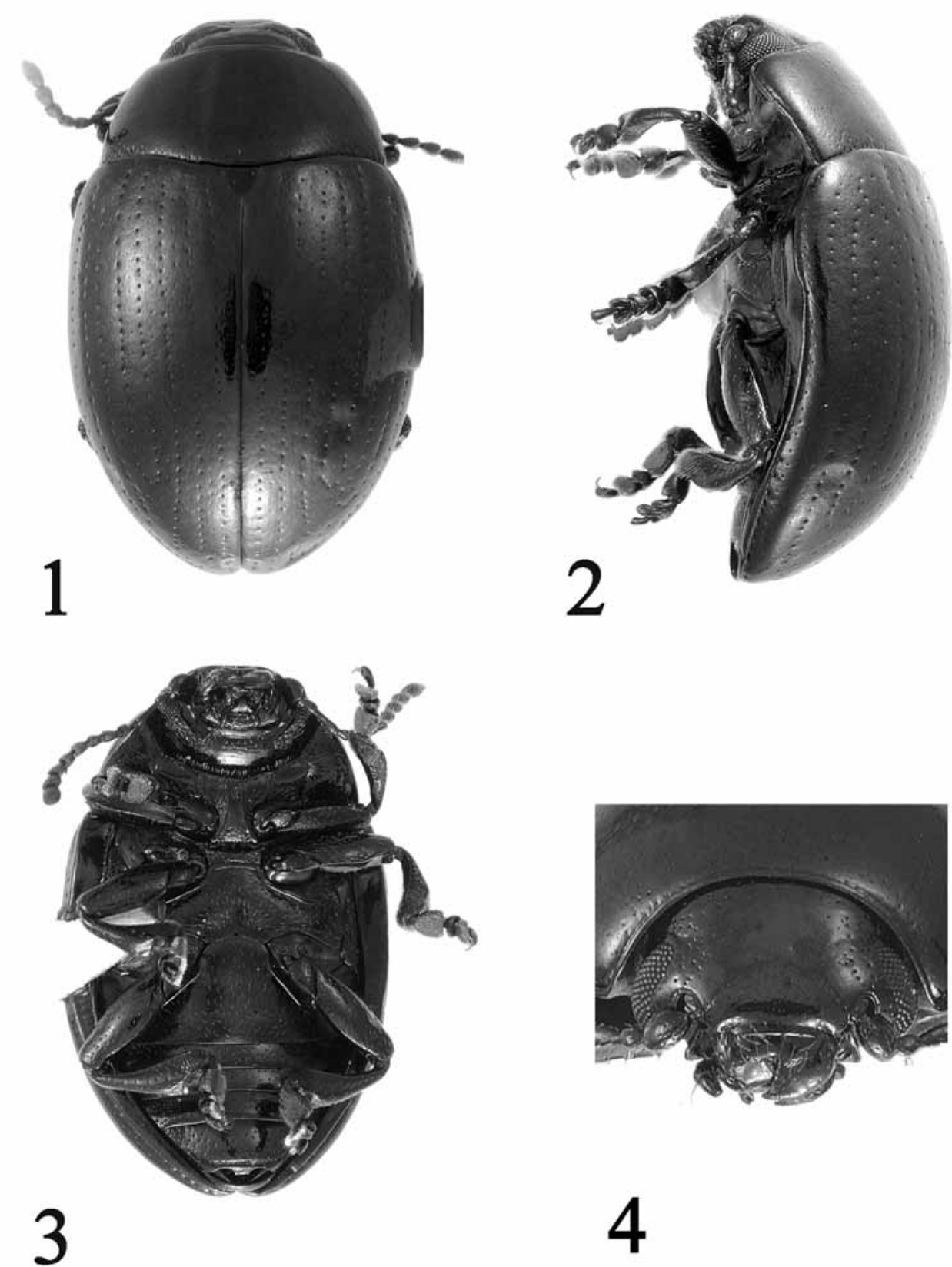

FIGURES 1-4. Canobolas nobilis (Lea), male: 1, dorsal; 2, lateral; 3, ventral; 4, face. 
No beetles have been observed feeding on plants. DNA data from plant fragments in a specimen of Canobolas nobilis suggest that the species is polyphagous (see under species description below).

Immature stages are unknown.

Etymology. The genus is named from the massif of Mount Canobolas, where the type species was collected. Canobolas means 'two shoulders' in the local Wiradjuri language (Anonymous 2003). The name is arbitrarily designated masculine.

Systematics. The new genus is most similar to the endemic Australian genera Cyclonoda Baly, Ethomela Lea, Eugastromela Lea, Geomela Lea, Gibbiomela Daccordi and Palaeomela Daccordi (Reid 2006a). It shares with them: body relatively small and ovoid; colour black or almost so, often with slightly metallic blue or green reflection; eyes laterally produced; trichobothria absent from each corner of pronotum. Gibbiomela and Palaeomela are easily distinguished from Canobolas: the former by the extremely narrow prosternal and mesoventrite processes and absence of subantennal grooves; the latter by closed procoxal cavities, absence of femoral plates, bilobed third tarsomeres and pygidium without median groove. Eugastromela is also easily distinguished, by its deeply grooved facial sutures, lack of antenna-retaining ridges and grooves on head and prosternum, tuberculate elytra, absent femoral plates, bilobed third tarsomeres and penis without basal split. The remaining genera, Cyclonoda, Ethomela and Geomela, are more similar in size and shape to Canobolas.

Geomela and Ethomela are distinguished from Canobolas by: mesoventrite process not abruptly raised, less transverse (width $<2 x$ length), with anterior margin not excavated to retain truncate apex of prosternal process; apex third tarsomere bilobed; apex last ventrite in male without rectangular internal flange; tegmen absent. Furthermore Ethomela has closed procoxal cavities and the tibiae of Geomela are not externally keeled.

Cyclonoda is distinguished from Canobolas by: male clypeus asymmetrically lobed; groove absent above eye; last maxillary palpomere elongate-cylindrical and truncate; elytral epipleura strongly sinuate, abruptly attenuate in apical third; metaventrite and first abdominal ventrite without femoral plates; pygidium without median groove; vaginal palpi 1-segmented.

On these criteria Canobolas is a distinct monophyletic group of species, possibly the sistergroup of Cyclonoda.

\section{Identification of Canobolas}

The recently published key to Australian genera of Chrysomelinae (Reid 2006a), with its correction (Reid 2006b), needs to be modified to accommodate Canobolas, as follows:

27(25) Length 3.5-7.0mm; anterior of prosternum laterally strongly obliquely ridged; eyes strongly transverse (width $>2.8 \mathrm{x}$ length); gena with long ridge and deep groove between eye and mouth; third tarsomere not bilobed.... 27a Length $<3.5 \mathrm{~mm}$; anterior of prosternum without lateral oblique ridges, or these faintly indicated; eyes less transverse (width $<2.8 \mathrm{x}$ length); gena with short ridge and groove, or not grooved; third tarsomere deeply bilobed, or apex rarely shallowly concave (some Geomela).....

27a(27) Anterior of metaventrite and first ventrite without femoral plates; pygidium without median groove...... Cyclonoda Baly Anterior of metaventrite and first ventrite with femoral plates; pygidium with deep median groove.

\section{Key to species of Canobolas}

1 Elytra shining, not microreticulate (Figs 1, 7); apex of each elytron with short obtuse tooth; elytral stria 9 incomplete (Fig. 2), at least erased on middle third; antennae short, antonnomeres 9-10 broad, length 0.9-1.0x width (Figs. 1314); posterior of pronotal disc finely and sparsely punctured in contrast to strongly punctured sides (Fig. 7); metaventrite femoral plates with sinuate posterior margins (Figs 17-18) (New South Wales) 
- $\quad$ Elytra duller, densely microreticulate (Figs 5-6); apex of each elytron with elongate acute tooth; elytral stria 9 entire on basal 3/4 of elytra; antennae long, antennomeres 9-10 distinctly elongate, length 1.3-1.6x width (Figs 11-12); pronotum finely and almost evenly punctured throughout (Fig. 6); metaventrite femoral plates with arcuate posterior margins (Figs 15-16) (Western Australia).

2(1) Punctures of basal half of elytral stria 3 separated by 2.5-3.5 puncture diameters (Fig. 7); apical strial punctures larger than basal; antennomeres 9-10 narrower, length = width (Fig. 14); first ventrite femoral plate smaller (Fig. 18); profile of penis thinner, without tip of flagellum visible in repose (Fig. 22) ..... tubrabucca sp. nov.

- $\quad$ Punctures of basal half of elytral stria 3 separated by 1-2 puncture diameters (Fig. 1); apical elytral punctures not enlarged; antennomeres 9-10 broader, length 0.9x width (Fig. 13); first ventrite femoral plate larger (Fig. 17); profile of penis thicker, with flagellum prominent in repose (Fig. 21) nobilis (Lea)

3(1) Body more elongate, length 1.4-1.5x width; elytral apices irregularly surfaced, with small elevations (Fig. 6); posterior margin first ventrite femoral plate broadly rounded (Fig. 16); apex of penis thinner and less curved in profile (Fig. 20) minang sp. nov.

- $\quad$ Body more rounded, length 1.1-1.25x width; elytral apices smooth (Fig. 5); posterior margin first ventrite femoral plate narrower, almost triangular (Fig. 15); apex of penis thicker and more curved in profile (Fig. 19)

jarrah sp. nov.

\section{Canobolas jarrah Reid, Jurado-Rivera \& Beatson, sp. nov.}

(Figs 5, 8, 11, 15, 19, 25)

Material examined. Holotype: $\precsim /$ Bridgetown WA Lea/ Cyclonoda pilula Clark W Australia/ (SAM); paratype (1): + , same data as holotype (SAM).

Description. Length: male $4 \mathrm{~mm}$; female $4.5 \mathrm{~mm}$. Shape: body short-ovate and strongly arched, length 1.1-1.25x width, length 1.8-2.1x height. Colour: body black, with faint greenish hue, appendages dark reddish-brown. Dorsal surfaces relatively dull, microreticulate throughout, reticulations coarse on elytra.

Head: frontoclypeus with large close punctures, frontoclypeal suture weak, base of clypeal area feebly depressed; antennae c. $0.5 \mathrm{x}$ (male) or c. $0.3 \mathrm{x}$ (female) body length; all antennomeres elongate, 9-10 length $1.3-1.5 \mathrm{x}$ width.

Thorax: pronotum closely and evenly punctured, intervals 1-3x puncture diameters; hypomeron entirely deeply transversely wrinkled; elytral striae 1-9 complete, 2-8 (female) or 2-9 (male) feebly impressed; punctures of striae 1-8 close, separated by $0.5-2$ puncture diameters; punctures of basal half stria 3 separated by 1-2 diameters; apical strial punctures not enlarged; interstrial punctures minute and obscured by microreticulation; apices of elytra with elongate acute apical tooth; metaventrite femoral plate triangular with posterior margin almost straight.

Abdomen: ventrites shining, microreticulate but weakly so, especially ventrite V; ventrites moderately strongly and closely punctured, with short recumbent setae; first ventrite with triangular femoral plate, half length of ventrite at this point; penis curved and evenly narrowed to apex in lateral view, with slightly angulate apex in dorsal view, flagellum present, but not visible laterally or dorsally, hidden by apical folds of endophallus; female sternite 8 with short apically forked spiculum; second segment vaginal palpi elongatecylindrical; spermatheca falcate, with rounded tip.

Distribution. Only known from the type locality, Bridgetown, south-western Western Australia. This locality is in the heart of the jarrah forests of Western Australia. On 24th November 2006 JAJR collected chrysomelines by grasstufting in this area, but failed to find Canobolas jarrah.

Etymology. Named after the forest tree jarrah (Eucalyptus marginata), from the local Noongar language (Abbott 1983), a noun in apposition.

Notes. The two specimens were carded together and have been remounted separately. They were misidentified as Cyclonoda pilula by Lea (see Systematics above for discussion of this genus). 


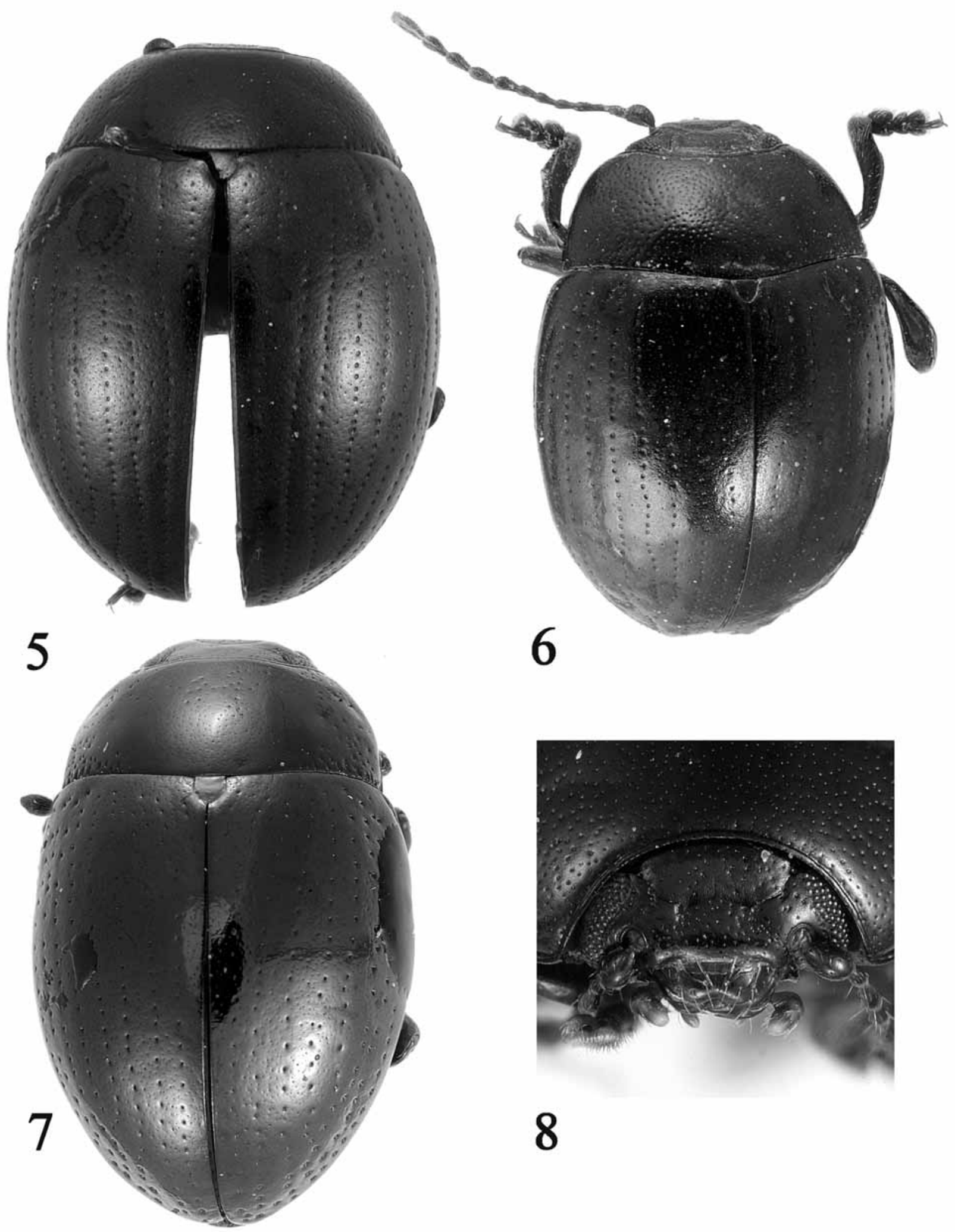

FIGURES 5-8. Canobolas species, dorsal: 5, C. jarrah sp. nov.; 6, C. minang sp. nov.; 7, C. tubrabucca sp. nov.; face: 8, C.jarrah sp. nov. 
Canobolas minang Reid, Jurado-Rivera \& Beatson, sp. nov.

(Figs 6, 12, 16, 20, 25)

Material examined. Holotype: $\delta /$ Chalcolampra arthritica Lea, K. G. Sound/ (MMS); paratypes (3): $2 \curvearrowright, 1 \uparrow /$ K. G. Sound/ (MMS).

Description. Length: male 3.5-4mm; female $5 \mathrm{~mm}$. Shape: body short-ovate and strongly arched, length 1.4-1.5x width, length 1.9-2.2x height. Colour: body reddish-brown to black, with faint greenish hue, appendages dark reddish-brown. Dorsal surfaces relatively dull, microreticulate throughout, reticulation coarser on elytra.

Head: frontoclypeus with small to large close punctures, frontoclypeal suture weak, base of clypeal area strongly depressed; antennae c. $0.5 \mathrm{x}$ (male) or c. $0.3 \mathrm{x}$ (female) body length; all antennomeres elongate, 9-10 length 1.4-1.6x width.

Thorax: pronotum closely and evenly punctured, intervals $1.5-3 \mathrm{x}$ puncture diameters; hypomeron entirely shallowly transversely wrinkled; elytral striae 1-9 complete, striae 2-8 (female) or 2-9 (male) feebly impressed; punctures of striae 1-8 close, separated by $0.5-2$ puncture diameters; punctures of basal half stria 3 separated by 1-3 diameters; apical strial punctures not enlarged; interstriae with scattered large punctures and more numerous minute punctures, latter obscured by microreticulation; apices of elytra with elongate acute apical tooth; metaventrite femoral plate triangular with posterior margin slightly convex.

Abdomen: ventrites shining, microreticulate but weakly so, especially ventrite V, moderately strongly and closely punctured, with short recumbent setae; first ventrite with semicircular femoral plate, half length of ventrite at this point; penis shallowly curved with thin apex in lateral view and rounded apex in dorsal view, flagellum not visible externally; female genitalia unknown (missing).

Distribution. Only known from the type locality, King George Sound, now Albany, south-west Western Australia. This area has significantly higher rainfall than the rest of the south-western bioregion.

Etymology. Named for the extinct indigenous language, Minang, local to the King George Sound area (Thieberger 1996): a noun in apposition.

Notes. One specimen was identified by Lea as Chalcolampra arthritica Lea, 1903, a species now in genus Ethomela Lea, 1916 (Reid 2006a). This is not a type specimen and was simply misidentified.

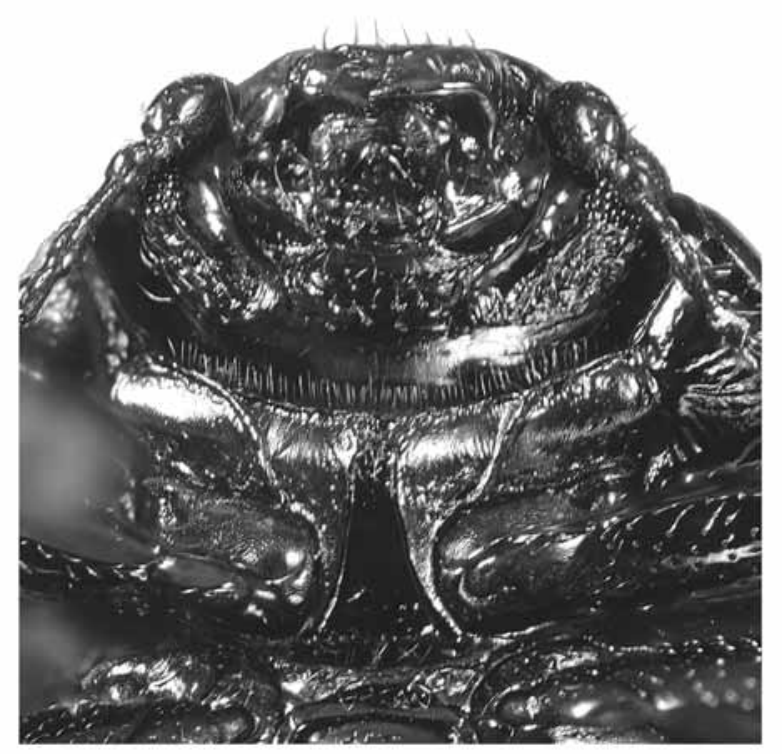

9

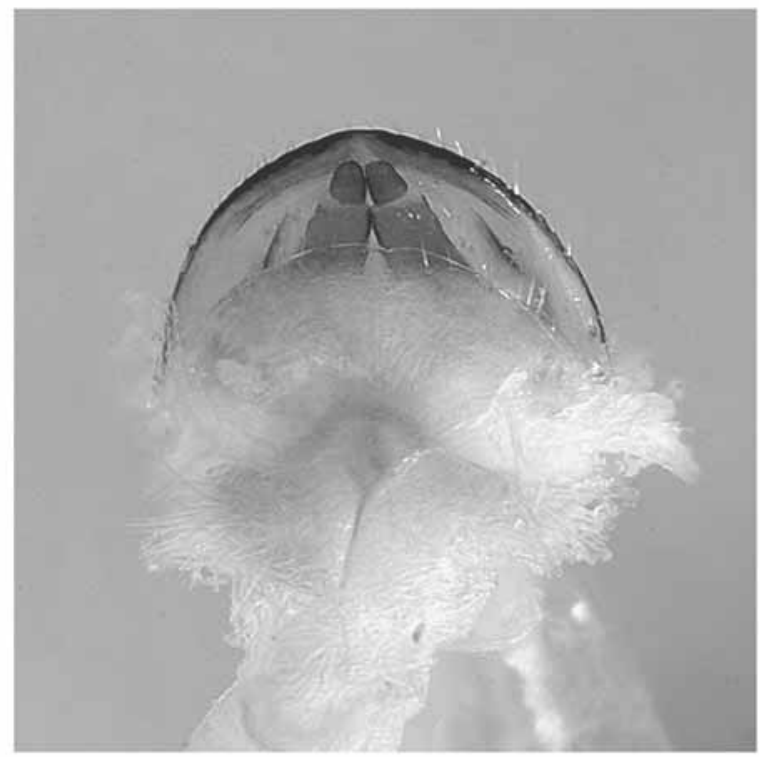

10

FIGURES 9-10. Canobolas nobilis (Lea): 9, venter of head and pronotum; 10, venter of ovipositor. 
Canobolas nobilis (Lea, 1917), comb. nov.

(Figs 1-4, 9-10, 13, 17, 21, 24-25)

Geomela nobilis Lea, 1917: 581

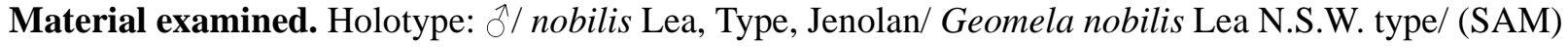

Other material (21). 1 $\Uparrow /$ Jenolan NSW 22.ii.1982 F. T. Fricke/ ex H. W. Brown coll./ poa sphagnum/ (AMS); 5^, 2 / NSW Mt Canobolas 33:20S 148:59E, c1395m, GPS\#163, 55H0684386-6308736, grass tussocks, alpine woodland, 19.x.2005, J. Jurado \& C. Reid/ (AMS); 1 / ditto except 1-2.xi.2005, J. Jurado/

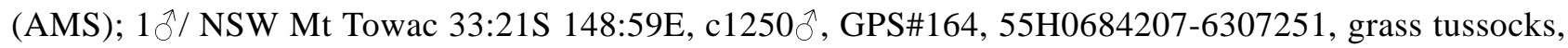
alpine woodland, 19.x.2005, J. Jurado \& C. Reid/ (AMS); 4^, 7이 Mt Canobolas, Federal Falls picnic area, 33:21S 148:58E, c1280m, GPS\#173, 55H0683946-6308188, grass tussocks, alpine woodland, 2-3.xi.2005, J. Jurado/ (AMS, ANIC, BMNH).
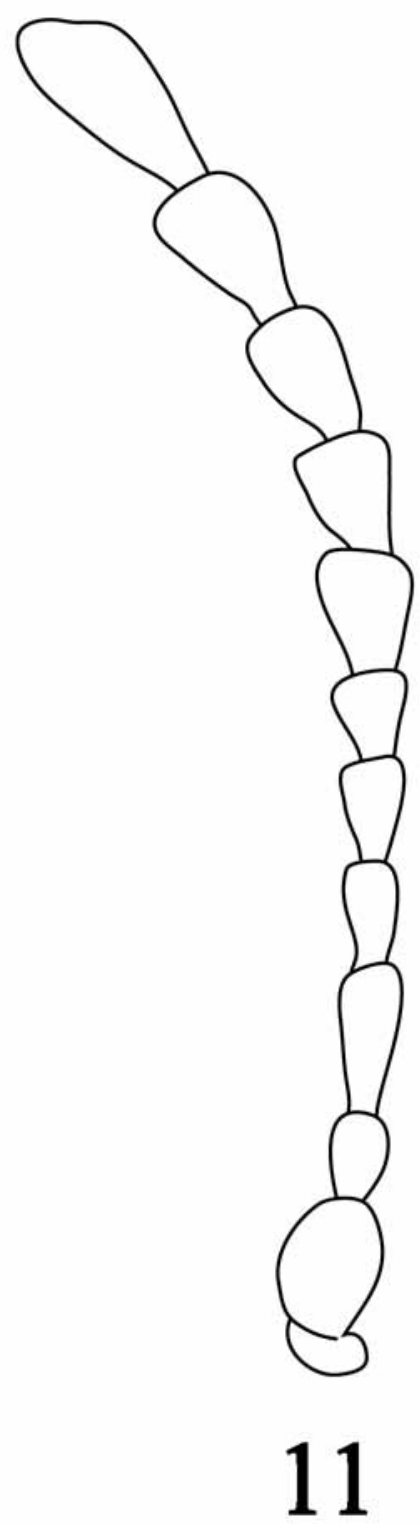

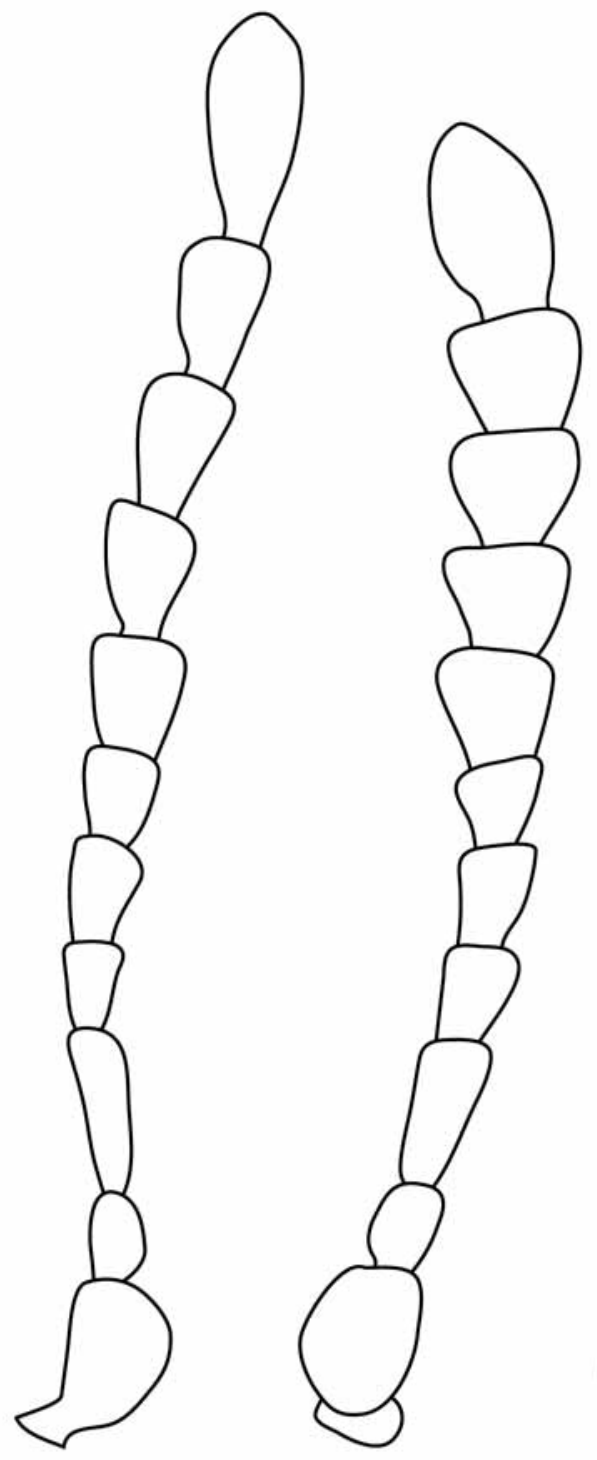

13
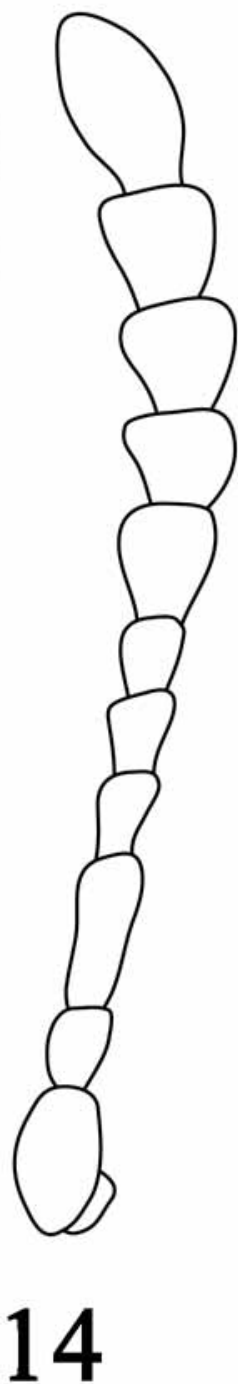

FIGURES 11-14. Canobolas species, male antenna (drawn to scale): 11, C. jarrah sp. nov.; 12, C. minang sp. nov.; 13, C. nobilis (Lea); 14, C. tubrabucca sp. nov. 

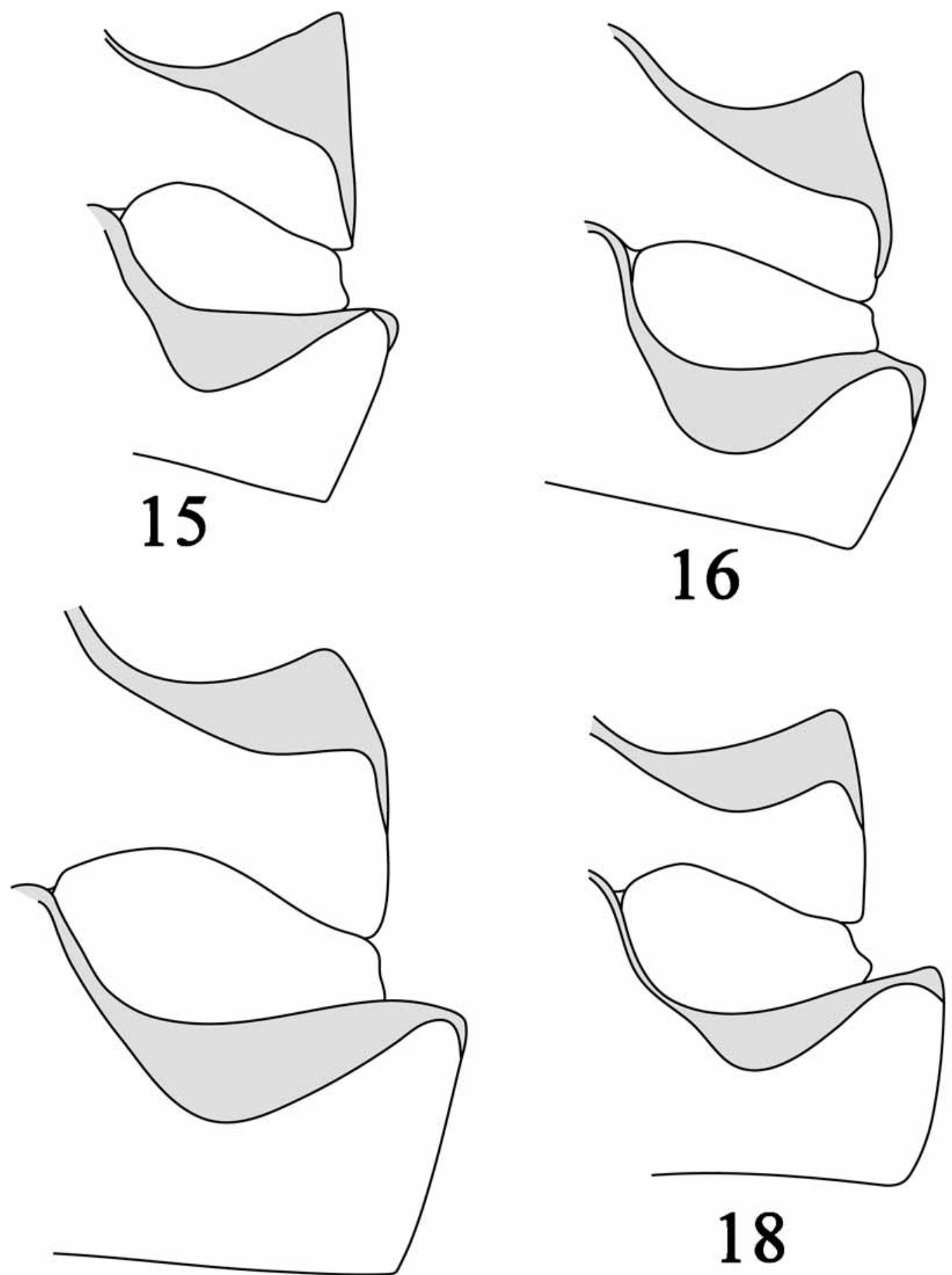

\section{7}

FIGURES 15-18. Canobolas species, partial right side of venter, showing metaventrite, metacoxa and first abdominal ventrite, femoral plates shaded (drawn to scale): 15, C. jarrah sp. nov.; 16, C. minang sp. nov.; 17, C. nobilis (Lea); 18, C. tubrabucca sp. nov.

Description. Length: male 4-5mm; female $5-5.5 \mathrm{~mm}$. Shape: body ovate and moderately arched, length 1.5-1.6x width, length 2.1-2.4x height. Colour: body and appendages black, with faint bluish, greenish or violet hues, or antennae and maxillary palpi dark reddish-brown. Dorsal surfaces shining throughout, without microreticulation, but evenly micropunctate (punctures not distinguishable at $<20 x$ magnification). 
Head: frontoclypeus with sparse fine punctures, generally sparser posteriorly, denser and often larger anteriorly and laterally, but the density varying between individuals; frontoclypeal suture strongly to weakly demarkated, base of clypeal area usually feebly depressed; antennae c. $0.4 \mathrm{x}$ (male) or $0.3 \mathrm{x}$ (female) body length; antennomeres 9-10 short, length 0.9-1.0x width.

Thorax: pronotal puncturation variable, sparsely to closely and evenly punctured, punctures fine at middle, larger but not denser anteriorly and laterally; hypomeron smooth or shallowly wrinkled at sides; elytral striae $1-8$ complete, slightly impressed, $9^{\text {th }}$ stria reduced to a few punctures in basal third or rarely also in apical third; strial punctures close, separated by 1-3 puncture diameters; punctures of basal half stria 3 separated by 1-2 diameters; apical strial punctures not enlarged; interstrial punctures sparse, variably sized but much smaller than strial punctures; apices of elytra with obtuse apical tooth; metaventrite femoral plate with posterior margin curved, slightly sinuate.
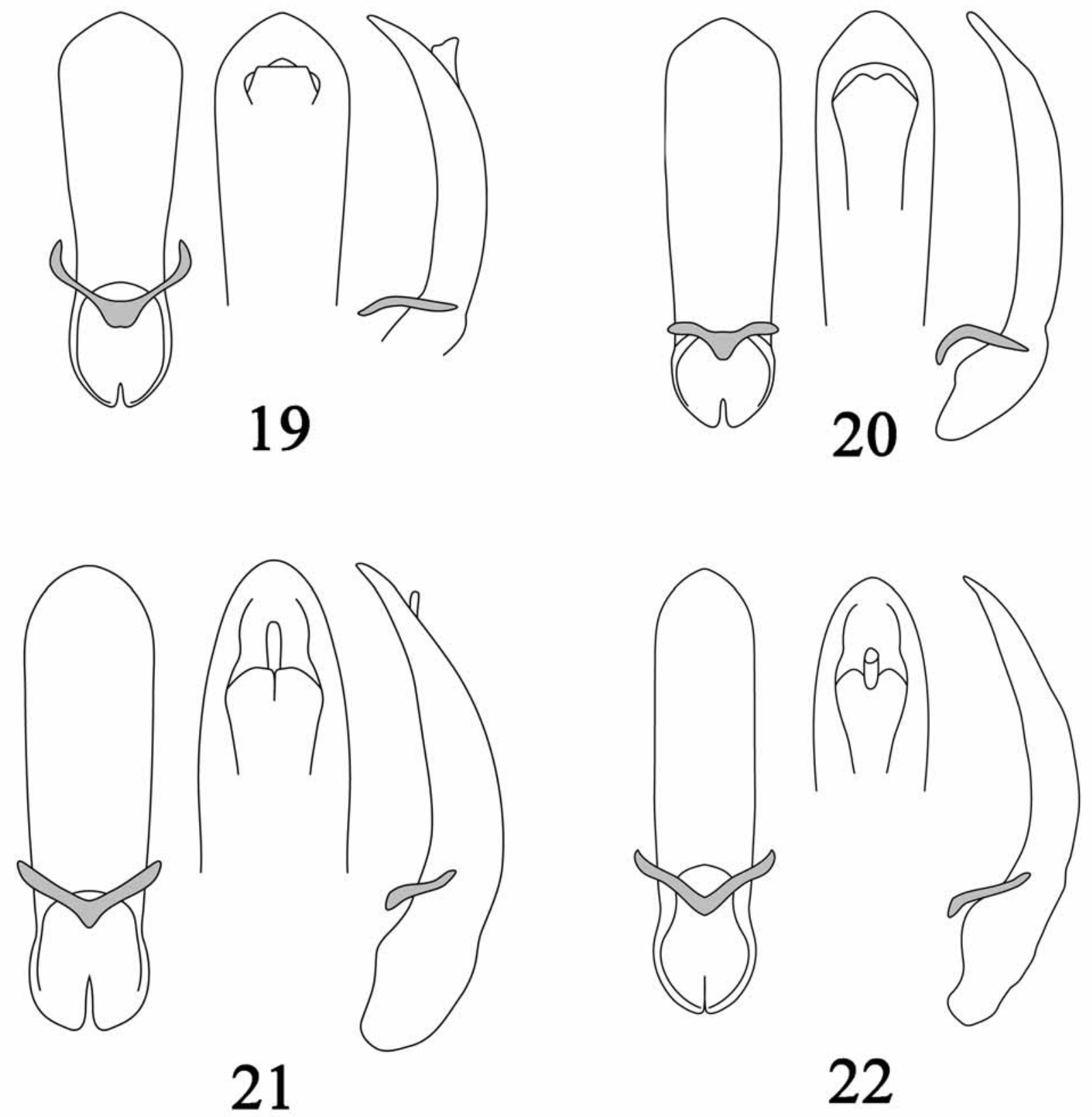

FIGURES 19-22. Canobolas species, male genitalia (drawn to scale): 19, C. jarrah sp. nov.; 20, C. minang sp. nov.; 21, C. nobilis (Lea); 22, C. tubrabucca $\mathbf{\text { sp. nov. }}$ 

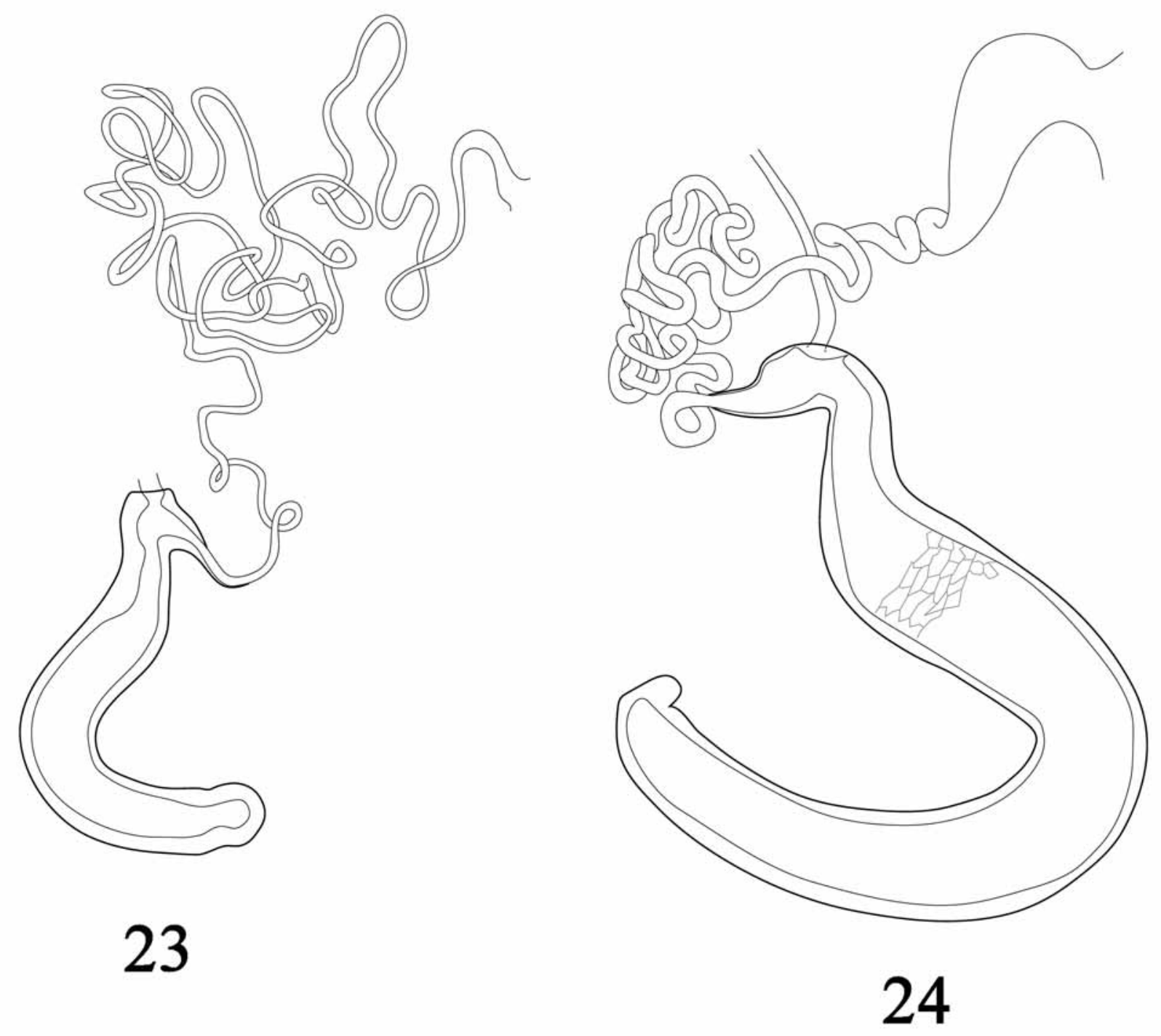

FIGURES 23-24. Canobolas species, female genitalia (drawn to scale): 23, C. jarrah sp. nov.; 24, C. nobilis (Lea).

Abdomen: ventrites I-IV evenly microreticulate, $\mathrm{V}$ without microreticulation; ventrites finely and sparsely punctured, more strongly and closely at sides, with short recumbent setae; first ventrite with broad arcuate femoral plate, c. $0.4 \mathrm{x}$ length of ventrite at this point; penis curved and abruptly narrowed to tip in lateral view, with rounded tip in dorsal view, flagellum slightly protruding from ostium in repose, visible in lateral view; female sternite 8 with long thin spiculum; second segment vaginal palpi elongate-ovate; spermatheca falcate, with hooked tip.

Distribution and biology. This species was described from a single specimen (Lea 1917). It is now known from Mount Canobolas and Jenolan, central eastern New South Wales. These are relatively high altitude $(>800 \mathrm{~m})$ localities in the western Blue Mountains separated by approximately $100 \mathrm{~km}$ of elevated landscape, mostly cleared or carpeted with Pinus radiata plantations (Anonymous 2003). At Mount Canobolas, 19 specimens of Canobolas nobilis were collected by grasstufting in herb rich snowgum woodland (dominated by Eucalyptus pauciflora) on the near-summit southern slopes, at 1250-1395m, during October and November (Fig. 26). These sites belong to the 'grasslands and grassy open woodlands' plant community in the Mount Canobolas reserve (Turner 2002), but the beetle always occurred under or near eucalypt trees.

The precise location of the Jenolan population is unclear, as the name Jenolan could be applied to a broad area of limestone gorge country from Jenolan Caves $(800 \mathrm{~m})$ to Jenolan State Forest $(1200 \mathrm{~m})$. Grasstufting by 
CAMR on 25 October 2008 at 1140-1200m in subalpine woodland remnants beside the road in Jenolan State Forest, dominated by Eucalyptus pauciflora, and at 800-900m in the vicinity of Jenolan Caves, failed to find any specimens of this species.

Feeding by adults was not observed in the field. We attempted to identify hostplants by two methods: laboratory rearing and barcoding plant tissues from whole specimen DNA extraction.

10 specimens of $C$. nobilis were collected by grasstufting mixed low herbs and grasses, and retained alive in the laboratory with a sample of the plants present, including Asperula (Rubiaceae), Geranium (Geraniaceae), Plantago (Plantaginaceae) and Poaceae. No feeding was observed during six weeks survival in captivity. These adults may have been aestivating.

However plant DNA sequences were obtained by JAJR from one specimen collected at Mount Canobolas in early November 2005 (lot \#173). Sequences from the chloroplast trnL intron from plant fragments in chrysomelids have been successfully used for identification of their hosts (Jurado-Rivera et al. 2009). The method consists of analyzing phylogenetically the diet sequence together with a set of closely related sequences from DNA databases, enabling identification of the host's taxonomic position. The P6 loop of the trnL intron was sampled from one specimen of $C$. nobilis by JAJR and found to be more diverse than any known species (Jurado-Rivera et al. 2009). Four different sequences were found belonging to 3 plant families with maximum support in phylogenetic analyses (Bayesian posterior probability $p p=1$ ): Caryophyllaceae, Myrtaceae and Solanaceae. One sample belonged to Caryophyllaceae, specifically either Stellaria or Cerastium, with a higher probability of Stellaria ( $p p=0.78$ ). Both the native Stellaria flaccida and the introduced weed Cerastium glomeratum occur in the snowgum woodland (Hunter 2002). Two sequences of Myrtaceae were recovered, without generic resolution. Only Eucalyptus and Leptospermum are present where the beetle was collected (Hunter 2002). One sample was identified as Solanaceae, although no members of this family are recorded from snowgum woodland at Mount Canobolas (Hunter 2002). These putative plant hosts are puzzlingly diverse and unrelated (Stevens 2009), but indicate that Canobolas nobilis is polyphagous.

\section{Canobolas tubrabucca Reid, Jurado-Rivera \& Beatson, sp. nov.}

(Figs 7, 14, 18, 22, 25)

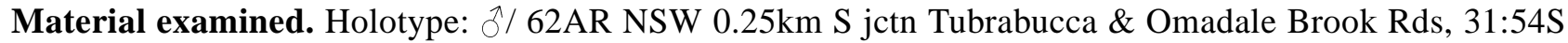
151:23E Stewarts Brook S[tate] F[orest] 1290m (NPWS Survey) 4 Feb-9Apr 1993 M. Grey \& G. Cassis/ K264047/ (AMS).

Description (male only). Length: male $4 \mathrm{~mm}$. Shape: body elongate-ovate and moderately arched, length $1.7 x$ width, length $2.2 x$ height. Body and appendages black. Dorsal surfaces shining, without microreticulation but evenly micropunctate (punctures not distinguishable <20x magnification).

Head: frontoclypeus with sparse fine punctures, frontoclypeal suture weak, base of clypeal area strongly depressed; antennae c. $0.4 x$ body length; antennomeres $9-10$ length $=$ width.

Thorax: pronotum finely and sparsely punctured on disc and base, intervals $2-5 x$ puncture diameters, strongly punctured laterally and apically; hypomeron entirely shallowly transversely wrinkled; elytral striae 1-8 complete, striae 4-8 feebly impressed; stria 9 reduced to basal third of elytra; punctures of striae 1-8 separated by $1-3$ puncture diameters; punctures of basal half stria 3 separated by $2.5-3.5$ diameters; apical strial punctures larger than basal; interstrial punctures minute but dense; apices of elytra with obtuse apical tooth; metaventrite femoral plate broad with sinuate posterior margin.

Abdomen: ventrites I-IV strongly microreticulate, ventrite V shining weakly microreticulate; ventrites moderately strongly and closely punctured, with short recumbent setae; first ventrite with shallowly arcuate femoral plate, c. $0.4 x$ length of ventrite at this point; penis shallowly and gradually curved in lateral view, with slightly angulate apex in dorsal view, apex of flagellum visible, but not protruding in lateral view.

Distribution. Only known from the type locality, Stewarts Brook State Forest, on the north-western plateau of the Barrington Tops massif, central eastern New South Wales. This locality is appximately $480 \mathrm{~km}$ 
north-east of the nearest location for $C$. nobilis and separated from it by the broad and deep Hunter Valley (Fig. 25), a well-known biogeographical barrier (Crisp et al. 1999). The specimen was collected in a pitfall trap. Grasstufting by CAMR on 13 December 2007 in Eucalyptus pauciflora woodland at 1370m, 8km northeast of the type locality, failed to find this species.

Etymology. From the local placename, Tubrabucca (a variant of tabrabucca: a ceremionial dance ground in the local Wiradjuri language, Reed 1967), a noun in apposition.
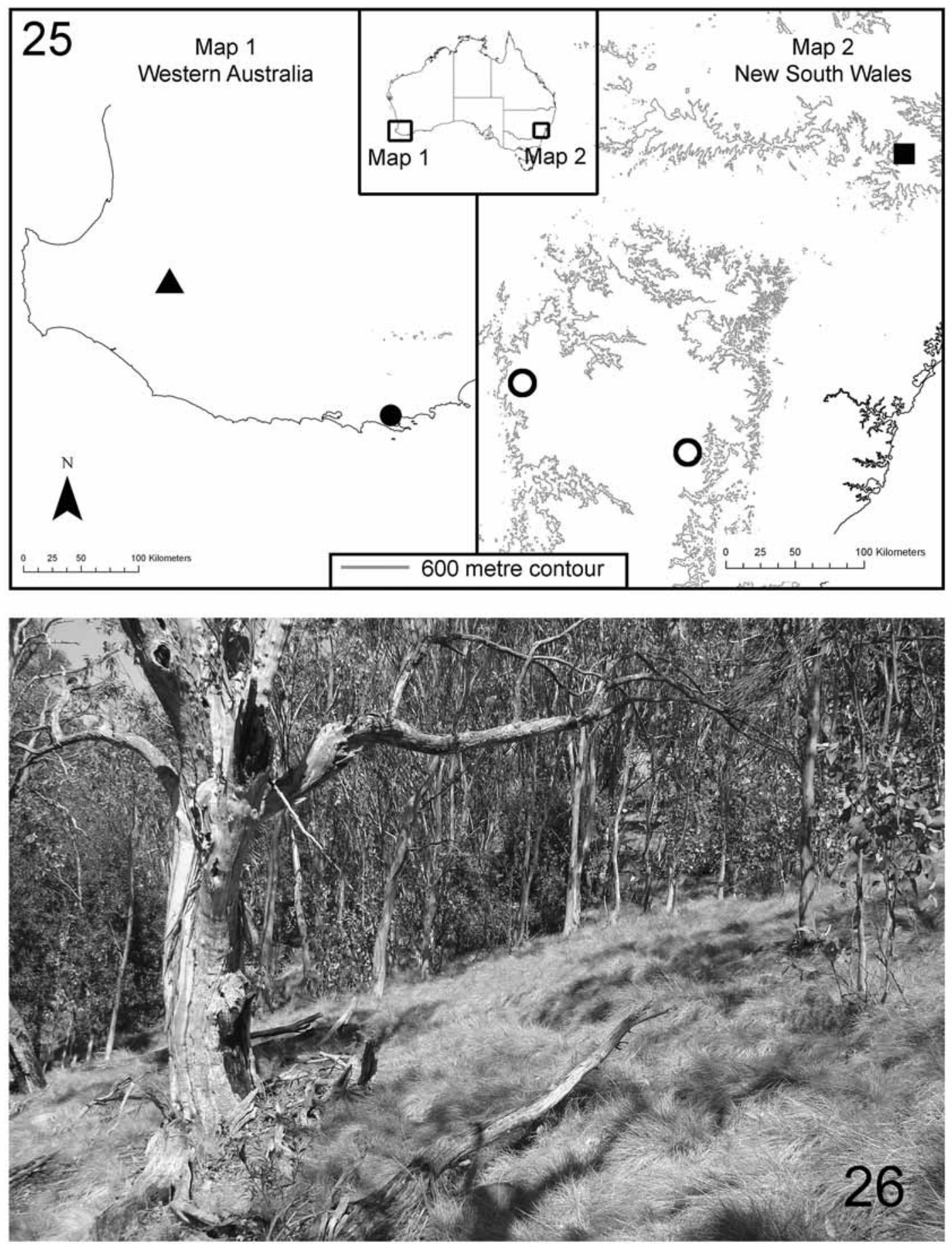

FIGURE 25. Maps of south-western and south-eastern Australia, showing localities for: Canobolas jarrah sp. nov. ( $\Delta$ ); C. minang sp. nov. (•); C. nobilis (Lea) (०); C. tubrabucca sp. nov. (•).

FIGURE 26. Snowgum (Eucalyptus pauciflora) woodland, 1380m, Mount Canobolas, New South Wales; habitat of Canobolas nobilis (Lea). Photographed 2 November 2006, José Jurado-Rivera. 


\section{Acknowledgments}

We are particularly grateful to Peter Gillespie (New South Wales Agricultural Scientific Collections Unit, Orange), for introducing us to Mount Canobolas, and to the New South Wales National Parks and Wildlife Service for collecting permits. We thank Liz Jeffries (MMS) and Eric Matthews (SAM) for permission to work on material in their care. JAJR's visits to Australia were supported by the Spanish Ministry of Education as a FPI doctorate studentship, and CAMR's work on Chrysomelinae has developed from funding by the Australian Biological Resources Study, for which grants both authors are extremely grateful. Thanks to Michael Elliott (Collection Informatics Unit, AMS) for Figure 25.

\section{References}

Abbott, I. (1983) Aboriginal names for plant species in South-western Australia, Forest Department of Western Australia Technical Paper, 5, 1-28.

Anonymous (2003) Mount Canobolas State Conservation Area plan of management. New South Wales National Parks and Wildlife Service, Hurstville, New South Wales. 30pp. [sighted online, October 2008: http:// www.environment.nsw.gov.au/resources/parks/pomfinalcanobolas.pdf]

Crisp, M.D., Linder, H.P. \& Weston, P.H. (1995) Cladistic biogeography of plants in Australia and New Guinea: congruent pattern reveals two endemic tropical tracks. Systematic Biology, 44, 457-473.

Daccordi, M. (1982) Chrysomelinae. [In: Seeno, T.N. \& Wilcox, J.A. (Eds). Leaf beetle genera (Coleoptera: Chrysomelidae)]. Entomography, 1, 75-95.

Daccordi, M. (1994) Notes for phylogenetic study of Chrysomelinae, with descriptions of new taxa and a list of all the known genera (Coleoptera: Chrysomelidae, Chrysomelinae). In: Furth, D.G. (Ed.), Proceedings of the third international symposium on the Chrysomelidae, Beijing, 1992. Backhuys, Leyden, 60-84.

Jurado-Rivera, J.A., Vogler, A.P., Reid, C.A.M., Petitpierre, E. \& Gómez-Zurita, J. (2009) DNA barcoding insect-host plant associations. Proceedings of the Royal Society, Series B, 276, 639-648.

Lea, A.M. (1917) Descriptions of new species of Australian Coleoptera. Part xiii. Proceedings of the Linnean Society of New South Wales, 42(3), 545-582, plate 29.

Matthews, E.G. \& Reid, C.A.M. (2002) A guide to the genera of beetles of South Australia. Part 8 Polyphaga: Chrysomeloidea: Chrysomelidae. South Australian Museum, Adelaide, 64pp.

Reed, A.W. (1967) Aboriginal place names. Reed New Holland, Sydney, 135pp.

Reid, C.A.M. (1995) Book review. Journal of the Australian entomological Society, 34, 224, 228.

Reid, C.A.M. (2006a) A taxonomic revision of the Australian Chrysomelinae, with a key to the genera (Coleoptera: Chrysomelidae), Zootaxa, 1292, 1-119.

Reid, C.A.M. (2006b) Erratum. Zootaxa, 1306, 68.

Thieberger, N. (1993) Handbook of Western Australian Aboriginal Languages south of the Kimberley Region. Pacific Linguistics, Canberra.

Turner, J.T. (2002) Vegetation and floristics of Mount Canobolas State Recreation Area, Orange, New South Wales, Cunninghamia, 7(3), 501-526. 